\title{
Security of the judicial power for sustainable development: a Ukrainian case
}

\author{
Olesia Bordun *
}

Received: 2021-03-15

Accepted: 2021-05-02

DOI: http:// doi.org/10.46489/lbsh.2021-1-1-3

\begin{abstract}
In this article, we have explored the constitutional principles of judicial security on the example of Ukraine. We found that researchers have not paid enough attention to the security system of the judiciary in Ukraine in the framework of sustainable development. We used the doctrinal legal research methodology to answer four research questions. First, we explored the content of the security concept in Ukrainian law. Secondly, we have established the extent to which the Constitution of Ukraine covers the security of the judiciary. Third, we described the distinction between internal and external threats to the security of the judiciary. Fourth, we have summarized the specific threats to the security of the judiciary mentioned in the Constitution of Ukraine. For each of the issues, we have provided recommendations to achieve sustainable development of Ukraine in the course of legal reform. As part of the discussion, we voiced recommendations for the participation of judicial selfgovernment and the Higher Council of Justice in ensuring the security of the judiciary. Our results complement the knowledge of the legal nature and constitutional principles of the judiciary. The presented recommendations can be used in formulating proposals for sustainable development strategies and directions of judicial reform.
\end{abstract}

Keywords: security of the power branch, threats to the judiciary, judiciary reform, sustainable development goals.

\footnotetext{
* Olesia Bordun, lecturer, Department of judiciary, prosecution and advocacy, Lviv university of business and law, Kulparkivska, 99, 79021 Lviv, Ukraine, e-mail: olbordun@meta.ua, ORCID: https://orcid.org/0000-0003-2801-0609 (corresponding author)
} 


\section{INTRODUCTION}

One of the goals of sustainable development is to ensure equal access to justice for all (Djeffal, C., 2018). Access to justice is also a condition of a fair trial within the meaning of the European Convention on Human Rights (Vuille, J., Luparia, L., \& Taroni, F., 2017).

When we talk about national security, we mean protecting citizens from external threats (McCormack, T., 2015). However, how can we describe the state of protection from threats posed by a particular branch of government? Access to justice depends on the state as a whole (Roach, K., \& Sossin, L., 2010), but barriers to access in one way or another concern the judiciary (Johnson, C. L., 2021). Equal access to justice cannot be achieved if there are certain threats in the judiciary (Bernatt, M., 2019).

Traditionally, the development of the conceptual foundations of the judiciary's security takes place within the methodological framework of the principle of judicial independence (Randazzo, K. A., Gibler, D. M., \& Reid, R., 2016). It is in this paradigm that the Decision of the Council of Judges of Ukraine dated October 2018 reads: "Security of judges and protection of court premises is one of the main guarantees of independence of judges and the justice system in general... situation with protection of courts, personal safety of judges and members families, court employees, ensuring the safety of participants in the trial remains extremely critical" (Council of Judges of Ukraine, 2018). But the security of the judiciary is a complex issue for which we must take a systematic approach (Chan, K.-W., 2011). Thus, we aim to explore the current realities and constitutional aspects of ensuring the security of the judiciary in Ukraine.

\section{1. Literature Review}

The link between effective justice and sustainable development is evident. Tsintzos, P., \& Plakandaras, V. (2020) proved that the judiciary is part of social capital and supports sustainable development. Chemin, M. (2009) proved the existence of a causal effect of the judicial system on specific components of sustainable development.
Sustainability in the state can be achieved only based on the approved rule of law. Gutmann, J., \& Voigt, S. (2018) argue that there is a link between sustainable development and the state's degree of the rule of law. Applied aspects of implementing the principle of the rule of law Gomes, T. M. R. C. (2017). According to the study results, the scientist confirmed the influence of the rule of law on sustainable development.

The condition for the rule of law is an absolute separation of powers. Poor distribution of power poses a threat to each of the branches. Hamilton, J., \& Slutsky, S. (2017) noted that only a robust judicial branch of power ensures complete separation of powers. Kovács, K., \& Scheppele, K. L. (2018) described the problems that affected the development of Hungary and Poland. Such problems arose from the violation of the described principle and linked threats to the judiciary of these countries.

Prylutskyi, S., \& Strieltsova, O. (2020) noted the presence of chronic problems in the organization and reform of the judiciary in Ukraine. Scholars touched on the issue of judicial independence in the light of geopolitical fluctuations. Romanenko, Y. O. (2018) analysed the impact of judicial reform on access to justice. The researcher noted the presence of negative trends, which we regard as threats to sustainable development.

Cooper, C. S. (2007), while examining the evolution of the concept of "court security", rightly notes that its content in the 70-80s of the twentieth century included the content of physical protection of the court and its occupants. However, in the XXI century, this concept already describes the protection of "all elements of judicial operations" and is fundamental to ensuring the integrity, continuity and independence of justice and is generally a prerequisite for achieving the rule of law. Campbell, C. F., \& Reinkensmeyer, M. W. (2007) noted that the concept of court security covers a wide range of issues and ranges from the physical protection of judges to education, from workplace violence to data integrity and architecture. 
The analysis of certain groups of threats is typical for empirical studies of the security of the judiciary. For example, Greacen J. M., \& Klein R. J. (2001) addressed aspects of court security, such as policies and procedures, access security, security of movement in court, movement and retention of defendants, threats to judges and court staff, implementation and forecasting, training and coaching, as well as technical and technological equipment.

There is also a debate in scientific research about the appropriateness of excessive spending on the judiciary's security. Gould, J. B. (2007) identified problems with inconsistencies in public expectations about security measures and the limits of their implementation, inconsistent monitoring of security measures, and significant gaps between increased public expectations about security and the realities of limited resources to perform these tasks.

Sarre R., \& Alikki V. (2013) investigated court security. In methodological terms, researchers emphasize accessibility to a safe court as a condition for respect for the right to a fair trial. According to the research of Sarre R., \& Alikki V., it is concluded that the goals of securing the court can be achieved with proper prior preparation and collection of information, development of the correct design of court security and the processes that take place in it. According to scholars, court security should be addressed by the court administration while noting that "strict" security is necessary but insufficient to ensure public access to a secure court (Sarre R., \& Alikki V., 2013).

A review of sources shows that, despite the urgency of this problem, comprehensive studies of the constitutional principles of judicial security in Ukraine have not been conducted.

\section{2. The theoretical and legal} background of the judiciary's security role in the process of sustainable development of Ukraine

In the Annual Report, the Higher Council of Justice (Ukraine) (2019) noted an increase in legislative initiatives that threatened the constitutional guarantees of judges' independence. As HCJ noted, there are too many ways the legislative and executive powers can intervene and interfere judiciary. It can endanger or threaten the independence of the judiciary.

Analysing the Law of Ukraine "On National Security of Ukraine" (2018), we found that ensuring the security of the judiciary is (unreasonable, in our opinion) not mentioned in this Law. According to paragraph 2 p. 1 art. 4 of the Law, judicial authorities belong to the system of civil control and carry out judicial control following the provisions of art. 9. According to this article, decisions, actions or omissions of public authorities, officials and officials may be appealed in court, and the courts exercise control over the execution of court decisions. Also, p. 2 art. 11 of the Law stipulates that citizens who believe that decisions have violated their rights, freedoms or legitimate interests, actions, the inaction of the components of the security and defence sector or their officials, have the right to go to court. A natural question that arises in this context is whether a threat to national security should not be considered a threat to the judiciary, whose bodies are involved in measures related to national security? This question, of course, is beyond the scope of our study but is promising for further research.

Insufficient attention is paid to the security of the judiciary in the National Security Strategy of Ukraine, which is, according to p. 1 art. 26, the main document of long-term planning, which defines the main directions of state policy in the field of national security. At the time of writing, the latest document is the Strategy of National Security of Ukraine "Human Security - Country Security") (Ukaz Pro rishennia Rady natsionalnoi bezpeky i oborony Ukrainy vid 14 veresnia 2020 roku «Pro Stratehiiu natsionalnoi bezpeky Ukrainy» No 392/2020 (Prezydent Ukrainy), 2020).

In line with the title of this Strategy, we see an essential emphasis on personal security. How does this affect the positioning of the security of the judiciary in the system of national security measures? Let us look at p. 46 of the Strategy, which begins with the following provision: "The citizen must feel safe". Thus, one of the responsibilities assigned to the state to implement the constitutional principles of individual legal responsibility and the inevitability of punishment is to establish adequate access to justice, improve the pre-trial 
investigation of criminal offences, and trial, criminal proceedings and execution of court sentences. In the same paragraph, we should note that there is such a part as "ensuring transparency, accountability of state bodies, the integrity of officials"; in other words, even the obligation to continue judicial reform has been diffused and merged with the administrative reform that is of concern.

No less paradoxical is the fact that the Strategy contains measures inherent in judicial reform. For example, "improve legislation on the organization of the judiciary and ensure fair justice". This requirement we can find in the paragraph describing the task of "ensuring the well-being and security of citizens, who need resources that, with the involvement and efficient use of external sources, can ensure sustainable and dynamic economic growth".

A cursory analysis showed that in the conditions of insufficient completeness of theoretical and methodological support of activities related to the security of the judiciary, the latter is not included in the system of measures related to national security, and therefore remains out of the attention of security researchers. In turn, the exclusion of this issue from the agenda of security research does not allow the proper development of theoretical provisions, indicating the emergence of a vicious circle.

In this paper, we have considered the following research questions:

$\mathrm{RQ}_{1}$. How is the concept of security covered in Ukrainian legislation?

$\mathrm{RQ}_{2}$. To what extent does the Constitution of Ukraine cover the issue of security of the judiciary?

$\mathrm{RQ}_{3}$. Is there a distinction in the Constitution of Ukraine between internal and external threats?

$\mathrm{RQ}_{4}$. Do the Constitution of Ukraine identify specific threats to the security of the judiciary?

\section{METHODS}

The Constitution of Ukraine strictly regulates the functioning of the judiciary. Thus, we performed research based on the doctrinal legal research methodology.

To answer the research questions, we first explored the concept of security using an information base of legal terms, supported by the Verkhovna Rada of Ukraine. We have summarised the essential criteria that can be applied in analysing the norms of the Constitution of Ukraine, connected with the judiciary.

Therefore, we conducted a qualitative analysis of the Constitution of Ukraine to identify provisions relating to the ontological security of the judiciary, the delimitation of threats by source (internal and external) and the specification of individual threats. We also discussed the possibility of clarifying the subjects of ensuring the security of the judiciary in the process of sustainable development goals achieving.

The following arguments can confirm the adequacy of this technique.

1. We performed research from the standpoint of a systems approach. We represent the security of the judiciary in the form of a system with separate elements and connections between them.

2. In Ukraine, there is no special law, which can cover all legal relations related to the security of the judiciary.

3. In Ukraine, there is no strategy for developing the judiciary consistent with sustainable development goals.

\section{RESULTS}

\subsection{The concept of "security" in Ukrainian law}

The laws of Ukraine do not contain a definition of "security". In the bylaws of Ukraine, the term security figures as (Bezpeka, 2020):

- the absence of unacceptable risk associated with the possibility of causing any harm to life, health and property of citizens and the environment;

- the absence of unacceptable risk associated with injury or death, damage to the environment;

- the absence of unacceptable risk associated with the possibility of harm and/or damage;

- a set of measures and human and material resources designed to protect civil 
aviation from acts of unlawful interference and other unlawful encroachments;

- the property of the object to ensure the absence of risk of harm to human health, property and the environment;

- a condition in which the risk of harm or damage is limited to an acceptable level;

- state when no threat to life, health, property, animals, plants, and the environment exceed the maximum risk;

- preventing the use of explosives, which is against the law and threatens public order;

- prevention of use that is against the law and threatens the order;

We found that the available definitions are highly diverse. However, these definitions have specific characteristics that we can consider when studying the judiciary's security.

First, concerning the essence of security, we observe the interpretation of the relevant term to denote the state, properties or properties of the object and a set of measures and actions to prevent the occurrence of an undesirable event.

Second, bylaws contain different terms (threat, risk, illegal encroachment) to denote events whose occurrence is undesirable to achieve security.

Third, groups of adverse events are detailed in bylaws depending on the type of security. Such groups may include damage to an individual, a group of people, property damage, damage to the environment, as well as damage to law and order.

Fourth, in some legal acts, there are absolute and relative assessments of harm, the prevention of which indicates safety. In particular, we are talking about the wording "no risk", which is evidence of the absolute inadmissibility of the occurrence of an adverse event, or the absence of harm that "exceeds the marginal risk" or risk that is "limited to an acceptable level."

Thus, we reach an intermediate conclusion that defining the concept of "ensuring the security of the judiciary" should assume the possibility of modifying individual elements depending on the characteristics of the elements included in the content of this concept.

\section{2. Does the Constitution of Ukraine cover the security of the judiciary?}

The Constitution of Ukraine (Konstytutsiia Ukrainy, 1996) has the highest legal force in Ukraine. So we based on the analysis of its content, which helps us establish general trends in the legal security of the judiciary.

Article 6 of the Constitution of Ukraine enshrines the separation of powers. In the second paragraph of this article, we find an indirect indication of the fundamental threat to the judiciary - the exercise of its powers by other branches of government. Indeed, otherwise, there is a risk of usurpation of power, which negates the security of the judiciary.

This provision is fundamental and can be interpreted from different angles. Its significance for preventing the ontological threat to the judiciary (threat to its existence) is obvious.

The ontological security of the judiciary is also enshrined in the provisions of p. 14 of the first paragraph of Article 92. It says that the judiciary, proceedings, the status of judges are determined exclusively by the laws of Ukraine. To a greater extent, this norm aims to resolve possible threats to the judiciary's influence at the level of bylaws. However, in conjunction with the second paragraph of art. 125 enshrines in the Constitution of Ukraine a multicomponent mechanism for ensuring the security of the judiciary at the court level, which "may be formed, reorganised and liquidated only by law". The President of Ukraine submits the draft law after consultations with the HCJ.

However, this threat is, to some extent, ephemeral. The current state of regulatory and legal support for the functioning of state bodies and, in particular, the judiciary creates confidence in the impossibility of the first type of threat. Therefore, we observe the legal community and society increasing attention to the second type of threat. Even in its Judgment, the Constitutional Court of Ukraine, in the case of the constitutionality of Article 375 of the Criminal Code of Ukraine, stated that "public relations in the field of justice are under constitutional protection in order to prevent actions contrary to the purpose of justice and prevent court decisions, which in essence 
cannot be an act of justice" (Constitutional Court of Ukraine, 2020). Thus, the Court shifted the emphasis on the expediency of constitutional protection as a tool for preventing internal threats to the justice system.

Article 124 of the Constitution of Ukraine, by its structure, contains norms aimed both at ensuring ontological security and preventing other threats to the security of the judiciary. In particular, the first and second paragraphs of this article enshrine the only possibility of administering justice in the courts, which is an element of the system of ontological security. The third and fourth paragraphs focus on establishing the court's jurisdiction, and the fifth on the direct participation of the people in the administration of justice.

Beginning with Article 126 of the Constitution of Ukraine, the legislator has paid considerable attention to two aspects of the security of the judiciary: the distinction between internal and external threats and the establishment of principles for overcoming more specific lower-level threats. The latter, however, are directly related to ontological threats. One such threat, illustrating the proposed distinction, is non-compliance with court decisions. The non-enforcement of court decisions is a systemic and permanent problem in Ukraine and raises numerous complaints to the European Court of Human Rights (Voitovych, P., Ennan, R., \& Voloshyna, V., 2020).

In Article 1291 of the Constitution of Ukraine, the first paragraph indicates the obligation to enforce a court decision. This is an element of the ontological security of the judiciary. The ECHR considers the right to a fair trial to be "illusory" in the event of nonenforcement of a court decision (Brems, E., \& Gerards, J. (Eds.), 2013). The second paragraph imposes on the state the obligation to enforce the judgment. Otherwise, imposing such an obligation on the judiciary would create a set of external threats. At the same time, the exclusion of the judiciary from participating in the enforcement of court decisions is in itself a threat. Therefore, the third paragraph clarifies that "the court exercises control over executing a court decision".

\subsection{Internal and external threats to the security of the judiciary}

The provision of the fourth paragraph of Article 62 of the Constitution of Ukraine is essential when assessing the modern mechanism for ensuring the security of the judiciary. It defines the entity responsible for compensation for pecuniary and non-pecuniary damage in the event of revocation of a court judgment on the grounds of injustice. According to the logic of separation of powers, the responsible subject, in this case, should be the judiciary. However, in the Constitution, such a subject is the state. We interpret this provision as an element of the mechanism for ensuring the security of the judiciary. Its purpose is to distinguish between internal and external threats to the judiciary. If an unjust decision is a threat of an internal nature (since judges can only cause it), then the imposition of an obligation to compensate the judiciary's related damage can be considered a significant threat from an external source.

The same approach we found in Article 126 of the Constitution of Ukraine. Paragraphs 1 to 5 provides guarantees aimed at preventing external threats to the security of the judiciary by establishing requirements related to the independence and immunity of the judge. Note the complementary provision of Article 126, paragraph 4 , concerning the fourth paragraph of Article 62. This paragraph establishes the functional immunity of a judge and, at the same time, determines the only possibility of prosecuting a judge in the event of an internal threat (commission of a crime or disciplinary offence). It is worth noting the imperfection of the wording of this paragraph, which we associate with the attempt to combine in one constitutional provision the principles of ensuring the internal and external security of the judiciary. Thus, according to the rules established by international standards, to ensure the independence and impartiality of judges, the latter must have immunity for the ordinary administration of justice. Horodovenko V.V. (2020) performed detailed review of this issue. Thus, in our opinion, the legislator should pay more attention to the delimitation of elements by the source of threats. In particular, the issue of a judge's functional immunity (element of the prevention of external threats) should be 
distinguished from bringing a judge to justice for committing a crime or disciplinary misconduct (element of prevention and overcoming of internal threats).

Such a recommendation is also helpful for reconstructing Article 126 of the Constitution of Ukraine. We observe that with some exceptions, which are more related to the judge's labour rights, dismissal of a judge relates to the judiciary's internal security issues. The same considerations apply to grounds for termination of service, which pose a set of internal threats to the judiciary. Paragraph 8 of Article 126 contains a guarantee of the personal safety of a judge and members of his family. On the one hand, it points to the security vector of the article as a whole.

On the other hand, we believe that placing such a guarantee in this place does not correspond to the article's logic. We also noted the imperfection given in terms of applying the term "personal security", as this concept is narrower than the "professional security" of a judge. The same remark we can sound to the last paragraph of Article 129, which establishes a guarantee of respect for the court and the judge.

By its construction, Article 129 is devoted to forming constitutional preconditions for ensuring the right to a fair trial. At the same time, it contains the provision as mentioned earlier concerning the security of the judiciary. The finding that the perpetrators have been prosecuted for contempt of court or judge indicates that contempt is a threat. This threat is obviously due to the peculiarities of ensuring the right to a fair trial. So, the fifth paragraph of Article 129 should be included in a separate article on the security of the judiciary.

\subsection{Concretization of threats to the judiciary's security and their impact on opportunities for sustainable development}

Sustainable development means that we leave our descendants with a better situation than we live in today. Any legal reform must comply with this postulate. The security of the judiciary will ensure that the rights of our descendants are better protected than ours.

In this context, we can identify several modern features of the security of the judiciary.
Addressing the fundamental aspects of the security of the judiciary (which include the authority and independence of the judiciary), the legislator in the Constitution clarified specific threats that may have a conflict with human rights. As follows from the content of Article 34, one of such threats is disseminating information that poses a threat to justice. Detailing the restrictions on the formation and operation of organisational structures of political parties in the judiciary (given in the third paragraph of Article 37 of the Constitution of Ukraine) indicates the threat of politicisation of the court.

Articles 127 and 128 are devoted to the requirements for judges and the procedure for their appointment. As the systematic analysis of these articles shows, their provisions aim to prevent several threats to the personnel security of the judiciary. The provision of Article 130 is also devoted to a particular type of security of the judiciary (financial security). In addition to establishing financial guarantees for the functioning of the courts and the activities of judges, the first paragraph of Article 130 enshrines the guarantee of certain "appropriate conditions". Nevertheless, the interpretation of the corresponding concept was not offered. So, we have a reason to consider it to some extent redundant in the design of the analysed article. In particular, the state does not directly deal with the issues of organisational support of justice. These powers belong to the State Judicial Administration of Ukraine. Therefore, funding guarantees would be sufficient to establish the grounds for the financial security of the judiciary.

We also found a good moment. In the construction of Article 130, again, as in Article 129-1, the legislator provided additional levers that allow the judicial authorities to contribute to the security of the judiciary. Thus, according to the provisions of the first paragraph of Article 130, the costs of maintaining the courts are determined by the parliament during the adoption of the Law of Ukraine "On the State Budget". However, the Higher Council of Justice is involved in this process by submitting proposals that should be taken into account in the State Budget of Ukraine. 


\section{DISCUSSION}

The Constitution of Ukraine contains certain elements that indicate the security of the judiciary. However, a positive impact on sustainable development arises when the provisions of the Constitution are in force. To this end, the Constitution and Laws of Ukraine confer powers on specific entities. The most important powers (in the conditions of established functioning of the security system of the judiciary) are control.

Articles 130-1 and 131 clarify the primacy of control within the system. According to the provisions of art. 130-1, for protection of professional interests of judges and the decision of questions of the internal activity of courts judicial self-government operates. Although the special law on the judiciary (according to which judicial self-government operates) somewhat smooths out the wording of this article, we should pay attention to two bottlenecks.

First, we consider it inexpedient to limit the powers of judicial self-government by protecting only the professional interests of judges. The concepts of professional interests, professional rights and professional security intersect in separate elements but are not identical. Furthermore, in this list, the concept of professional interests is perhaps the narrowest.

Second, the current wording does not shed light on whether the internal affairs of the courts include security issues and, if so, why these issues do not apply to judges.

Also relatively narrow are the areas of participation of the Higher Council of Justice in ensuring the security of the judiciary. They arise from the powers enshrined in Article 131. The analysis of the list of powers given in the first paragraph of this article indicates the participation of HCJ in ensuring the elements of ontological (p. 7), personnel (p. p. 1-4) and professional security of the judge (p. p. 5, 5).

As we can see from the above analysis, the powers of the HCJ defined in the Constitution of Ukraine are the most widespread and have not been aimed at fully establishing the role of this authority in ensuring the security of the judiciary.

Analysing the construction of Article 131, we found another weakness. It illustrates the incompleteness of the regulatory framework for the formation of organisational and legal mechanism for ensuring the security of the judiciary.

We are talking about paragraph 10 of Article 131, which states that "According to the law, bodies and institutions are established in the justice system to ensure the selection of judges, prosecutors, their professional training, evaluation, consideration of cases of their disciplinary responsibility, financial and organisational support of the courts".

First, the placement of this provision in this article should specify the role of the HCJ. Secondly, as evidenced by the results of a preliminary analysis of the Constitution's provisions, each of the above areas has its own "shadow". These are threats to the financial, organisational, personnel security of courts and the professional security of judges. The threats could become a "bridge" from the powers of the HCJ to these bodies. Third, we disagree with the attribution of judicial security to the sphere of "financial" or "organisational" support of courts. Therefore, we recommend the legislator include "ensuring the security of the judiciary" in paragraph 10 of Article 131 of the Constitution of Ukraine.

\section{This study has some limitations.}

The principle of the rule of law operates in Ukraine, and the Constitution of Ukraine has the highest legal principle. We have not investigated the provisions of the law on the judiciary. This legislation contains a more detailed description of the procedures for ensuring the security of the judiciary, which may complement, but do not contradict our observations.

This study's scientific significance and novelty are that the results we have obtained complement the knowledge of the judiciary's legal nature and constitutional principles. The Verkhovna Rada Committee on Legal Policy and the Judiciary can use the presented recommendations in formulating proposals on the Strategy of sustainable development and directions of judicial reform. Also, our research may be helpful for scientific institutions and foreign partners of Ukraine implementing joint projects in the field of judicial security. 


\section{CONCLUSION}

This study demonstrates a systematic approach to the security of the judiciary in Ukraine. We have found that the security of the judiciary is insufficiently covered in strategic documents related to sustainable development. Based on the analysis of bylaws, we identified features of interpreting the concept of "security". We have established that the Constitution of Ukraine contains provisions concerning the judiciary's ontological, personnel and financial security. The study confirmed that the Constitution distinguishes between internal and external threats to the security of the judiciary, but it is not clear enough. We have set out in the Constitution specific threats to disseminating information, independence and financial security of the judiciary. We discussed the possibility of clarifying the powers of judicial selfgovernment and the High Council of Justice to ensure the security of the judiciary. Finally, we set out proposals for the improvement of norms concerning the security of the judiciary in the light of the sustainable development of Ukraine.

\section{References}

1. Bernatt, M. (2019). Rule of Law Crisis, Judiciary and Competition Law. SSRN Electronic Journal. https://doi.org/10.2139/ssrn.3431631

2. Bezpeka [Security]. Terminolobiia zakonodavstva [Terminology of legislation]. Retrieved from https://zakon.rada.gov.ua/laws/term/1742 [in Ukrainian]. (2020, June, 02).

3. Borkowski, G., \& Sovgyria, O. (2019). Current Judicial Reform in Ukraine and in Poland:Constitutional and European Legal Aspect in the Context of Independent Judiciary. Access to Justice in Eastern Europe, 2(3), 5-35. https://doi.org/10.33327/AJEE-18-2.3-a000011

4. Brems, E., \& Gerards, J. (Eds.). (2013). Shaping Rights in the ECHR: The Role of the European Court of Human Rights in Determining the Scope of Human Rights. Cambridge University Press. https://doi.org/10.1017/CBO9781107337 $\underline{923}$

5. Campbell, C. F., \& Reinkensmeyer, M. W. (2007). The Court Security Challenge: A Judicial Leadership Perspective. Justice System Journal, $\quad$ 28(1), 49-
54. https://doi.org/10.1080/0098261X.2007.1076 $\underline{7824}$

6. Chan, K.-W. (2011). Justice System Reform and Legal Ethics in Japan. Legal Ethics, 14(1), 73108. https://doi.org/10.5235/1460728117963730 $\underline{41}$

7. Chemin, M. (2009). Do judiciaries matter for development? Evidence from India. Journal of Comparative Economics, 37(2), 230250. https://doi.org/10.1016/j.jce.2009.02.001

8. Constitutional Court of Ukraine. (2020). Decision in the case N 1305/2019(7162/19). https://zakon.rada.gov.ua/la ws/show/v007p710-20 [in Ukrainian].

9. Cooper, C. S. (2007). The Evolving Concept of "Court Security". Justice System Journal, 28(1), 40-45.

10. Council of Judges of Ukraine. (2018). Pro zakhody zabezpechennia bezpeky sudiv i suddiv, okhorony sudiv ta osib, kotri berut uchast u zdiisnenni sudochynstva [On measures to ensure the security of courts and judges, protection of courts and persons involved in the administration of justice]. https://zakon.rada.gov.ua/rada/show/v006541418\#Text [in Ukrainian].

11. Djeffal, C. (2018). Sustainable AI Development (SAID): On the Road to More Access to Justice. SSRN Electronic Journal. https://doi.org/10.2139/ssm.3298980

12. Gomes, T. M. R. C. (2017). Promoting the rule of law in Serbia. What is hindering the reforms in the justice sector? Communist and PostCommunist Studies, 50(4), 331337. https://doi.org/10.1016/i.postcomstud.2017. $\underline{10.004}$

13. Gould, J. B. (2007). Security at What Cost? A Comparative Evaluation of Increased Court Security. Justice System Journal, 28(1), 6278. https://doi.org/10.1080/0098261X.2007.1076 $\underline{7827}$

14. Greacen J. M., \& Klein R. J. (2001). Statewide Planning for Court Security. The ANNALS of the American Academy of Political and Social Science, 576(1), 109117. https://doi.org/10.1177/0002716201576001 $\underline{10}$

15. Gutmann, J., \& Voigt, S. (2018). The rule of law: Measurement and deep roots. European Journal of Political Economy, 54, 68- 
82. https://doi.org/10.1016/j.ejpoleco.2018.04.00 1

16. Hamilton, J., \& Slutsky, S. (2017). Judicial review and the power of the executive and legislative branches. Research in Economics, 71(1), 67-85. https://doi.org/10.1016/j.rie.2016.11.001

17. Higher Council of Justice. (2019). Shchorichna dopovid za 2019 rik "Pro stan zabezpechennia nezalezhnosti suddiv v Ukraini". [Annual report for 2019 "On the state of ensuring the independence of judges in Ukraine"]. https://hcj.gov.ua/sites/default/files/f ield/file/shchorichna dopovid za 2019 rik.pdf [in Ukrainian].

18. Horodovenko V.V. (2020). Dissenting opinion of the Judge of the Constitutional Court of Ukraine regarding the Decision in the case $\mathrm{N} 1$ 305/2019(7162/19). https://zakon.rada.gov.ua/la ws/show/ng-07d710-20\#n2 [in Ukrainian].

19. Johnson, C. L. (2021). Race, gender, class, and criminal justice: Examining barriers to justice. Race and Justice, 11(1), 121122. https:// doi.org/10.1177/2153368720908047

20. Konstytutsiia Ukrainy 1996 (Verkhovna Rada Ukrayiny). [Constitution of Ukraine 1996 (Verkhovna Rada of Ukraine)]. Ofitsiynyy sayt Verkhovnoyi Rady Ukrayiny. [The official website of the Verkhovna Rada of Ukraine]. Retrieved from https://zakon.rada.gov.ua/laws/show/254 $\% \mathrm{D} 0 \% \mathrm{BA} / 96-\% \mathrm{D} 0 \% \mathrm{~B} 2 \% \mathrm{D} 1 \% 80$ [in Ukrainian]. (2020, July, 18).

21. Kovács, K., \& Scheppele, K. L. (2018). The fragility of an independent judiciary: Lessons from Hungary and Poland-and the European Union. Communist and Post-Communist Studies, 51(3), 189-

200. https://doi.org/10.1016/j.postcomstud.2018. $\underline{07.005}$

22. McCormack, T. (2015). The British National Security Strategy: Security after Representation. The British Journal of Politics and International Relations, 17(3), 494511. https://doi.org/10.1111/1467-856X.12052

23. Prylutskyi, S., \& Strieltsova, O. (2020). The Ukrainian Judiciary under 21st-Century Challenges. Access to Justice in Eastern Europe, 3(23), 78-99. https://doi.org/10.33327/AJEE-183.2-3-a000027

24. Randazzo, K. A., Gibler, D. M., \& Reid, R. (2016). Examining the Development of Judicial Independence. Political Research Quarterly, 69(3), 583-

593. https://doi.org/10.1177/1065912916656277
25. Roach, K., \& Sossin, L. (2010). Access to justice and beyond. University of Toronto Law Journal, 60(2), 373395. https://doi.org/10.3138/utlj.60.2.373

26. Romanenko, Y. O. (2018). Second stage of judiciary reform in ukraine. Ukrainian assembly of doctors of sciences in public administration, 1(13), 183193. https://doi.org/10.31618/vadnd.v1i13.145

27. Sarre R., \& Alikki V. (2013). Access to Safe Justice in Australian Courts: Some Reflections upon Intelligence, Design and Process. International Journal for Crime, Justice and Social Democracy,

(2), https://doi.org/10.5204/ijcjsd.v2i2.116.

28. Tsintzos, P., \& Plakandaras, V. (2020). The judiciary system as a productivity factor; the European experience. Economics Letters, 192, 109257. https://doi.org/10.1016/j.econlet.2020.1 $\underline{09257}$

29. Ukaz Pro rishennia Rady natsionalnoi bezpeky i oborony Ukrainy vid 14 veresnia 2020 roku «Pro Stratehiiu natsionalnoi bezpeky Ukrainy» No 392/2020 (Prezydent Ukrainy). [Decree on the decision of the National Security and Defense Council of Ukraine of September 14, 2020 "On the National Security Strategy of Ukraine" No 392/2020 (President of Ukraine)]. Ofitsiynyy sayt Prezydenta Ukrainy. [The official website of the President of Ukraine]. Retrieved from https://www.president.gov.ua/documents/ 3922020-35037 [in Ukrainian] (2020, July, 6).

30. Voitovych, P., Ennan, R., \& Voloshyna, V. (2020). Criminal Liability for the Infringementof IP Rights: Ukraine and the EuropeanCourt of Human Rights Case Law. Access to Justice in Eastern Europe, 291297. https://doi.org/10.33327/AJEE-18-3.4$\underline{\mathrm{n} 000041}$

31. Vuille, J., Luparia, L., \& Taroni, F. (2017). Scientific evidence and the right to a fair trial under Article 6 ECHR. Law, Probability And Risk, $\quad$ 16(1), 5558. https://doi.org/10.1093/lpr/mgx001

32. Zakon Ukrainy "Pro natsionalnu bezpeku Ukrainy" 2018 (Verkhovna Rada Ukrayiny). [Law of Ukraine "On National Security of Ukraine" 2018 (Verkhovna Rada of Ukraine)]. Ofitsiynyy sayt Verkhounoyi Rady Ukrayiny. [The official website of the Verkhovna Rada of Ukraine]. Retrieved from https://zakon.rada.gov.ua/laws/show/2469-19 [in Ukrainian]. (2020, July, 5). 